\title{
Development of Teaching Materials in The Form of Digital Comic
}

\author{
$1^{\text {st }}$ Adek Cerah Kurnia Azis ${ }^{1}, 2^{\text {nd }}$ Sugito $^{2}, 3^{\text {rd }}$ Mesra $^{3}$ \\ \{adek_peros@yahoo.com ${ }^{1}$, sugitoas@gmail.com ${ }^{2}$, mesraa121@gmail.com ${ }^{3}$ \} \\ Department of Fine Arts, Faculty of Languages and Arts, Universitas Negeri Medan, Indonesia 1,2,3
}

\begin{abstract}
The aim of these research are; 1 ). the emission of Teaching Charts in the form of online and print-based comic books with the ISBN for Research Methodology Courses at publishers who have been registered as members of the Indonesian Publishers Association (IKAPI); 2). Disclosure of validation, practicality, and effectiveness of teaching materials in the form of online and printed ISBN-based comic books in Research Methodology Courses obtained from research results $91.62 \%$ are in the very valid category, the modulus value of students is in tertiary institutions at the level of $91.2 \%$ can be recognized very practical, this shows that the module is able to increase user interest in the learning process, and for student activities it is included in the active category because it is in the percentage of $79.64 \%$, and 3). scientific publications in the International Proceedings carried out by the LPPM, Universitas Negeri Medan, namely at the International Conference on Innovation in Education, Science and Culture and Scientific, publications in the Sinta-4 National Accreditation journal, namely the Journal of Expression of Arts, Science and Technology Institut Seni Indonesia Padangpanjang.
\end{abstract}

Keywords: digital comic, teaching materials.

\section{Introduction}

The correlation between interest and learning outcomes are two things that cannot be separated, a high learning interest in a course (MK) or a course material will affect a student's learning outcomes. Interest that does not exist at all, of course, will affect learning outcomes that are not good either. Starting from all of that, there will be a difference if someone has more interest or desire for a course or a course material, it will certainly get better learning outcomes, of course. There are several things that can be done to foster the interest mentioned above, especially in the Research Methodology Course at the Department of Fine Arts, Faculty of Language and Arts, Universitas Negeri Medan (Unimed), where this course is a very crucial course for students. This is because, this course is the first basis for students to make research later, if in lectures a student is less interested or not interested, it is certain that they will experience problems when carrying out future research.

So that this does not happen to students of the Department of Fine Arts, several things can be done to increase interest and interest in this course, among others, by developing Research Methodology Course Teaching Materials. This development can be in the form of printed books (printed), e-books (online) based on Android, and of course integrated with Unimed's SIPDA (Online Learning System) which aims to make it easier for students to learn and do assignments. given by a lecturer. Along with the development of technology to the current 
millennial era, there are some differences in the needs of "old" students and students of "now" era, in the past, lecturers always asked students to photocopy or buy books related to lecture material with a sufficiently thick and full copy capacity. text (containing a series of letters and numbers without any pictures), and the price of the book is quite expensive. Judging from the current state of being all gadgets, all information, be it education, health, lifestyle, and so on, is already in hand, so it is no longer suitable if a student has to photocopy thick books, then if a teaching material is full of text and numbers that are arranged from the beginning to the end of the book, this is certainly very boring for students, there is no interest in reading the book, it is different if a book is interspersed with pictures or there is an arrangement of colors so that there is something different, so students became curious and interested to read the book to the end. This is reinforced by the author's interview with several students of the Department of Fine Arts, namely Sudewo and his friends on Thursday, March 11, 2021, at 22:11 PM, from the results of student answers on this matter it can be concluded that "all students are more interested in books. which has an element of pictures, for various reasons including easier to understand, less boring, more fun when reading it, easier to understand the theory or study discussed, and so on". Based on the interview above, here the tendency of students is clear, namely the development of teaching materials with image or visual nuances.

Furthermore, in terms of student finances, expensive book prices are no longer the time for students, with the current development, there are many flat foams that provide cheap, practical, and efficient book services, through online book applications, where students can subscribe by paying around Rp. . 36.000,- can have e-books forever, can be accessed anywhere and anytime via their respective smart phones, this makes it very easy for students to learn. Based on the description of the phenomena above, there are many things that can be done to increase a student's interest in understanding the lesson and doing the tasks given by the lecturer per course, including interesting teaching media and practical, economical, and effective teaching media. efficient. Judging from the media that can increase student interest in getting better learning outcomes, especially for students of Fine Arts, one of the stimuli that the author can do is to make teaching materials in the form of comic books based on e-books (online) and print (printed). -International Standard Book Number (ISBN) in Research Methodology Courses that can be accessed, read, viewed, and studied by Fine Arts students through their respective gadgets, smartphones, smartwatches, androids, and laptops. Students can save, share these teaching materials on the Facebook (FB), Telegram WhatsApp (WA), Email, and so on applications, which are on the gadgets owned by the student, this activity can be carried out by students wherever they are, as long as the place is connected to the internet network. Development of teaching materials Methodology This research begins with compiling material according to the needs of students, in presenting the material equipped with pictures. The preparation of teaching materials is made as attractive as possible, so that students are interested and can understand easily.

There are many ways that can be done to increase the interest and learning outcomes of Fine Arts students, including by developing teaching materials. As said by Widodo and Jasmadi in Lestari (in Putri, 2016: 01-07), teaching materials are a series of facilities or something used in the teaching and learning process that contains materials, methods, limitations, and ways of evaluating that are designed systematically and interesting in order to achieve the desired goal, namely achieving competence or sub-competence with all its complexity. This definition illustrates that a teaching material should be designed and written with instructional rules because it will be used by lecturers, teachers, and other educators to assist and support the learning process. Learning (instructional), sources of information are lecturers, teachers, instructors, students, reading materials, teaching media, and so on. 
"Teaching media is a place and channel for messages from the source of the message, in this case the lecturer, to the recipient of the message, in this case the student"[1]. [2] Then Hernawan said that learning is one component that must exist, because it is a component that must be studied, observed, studied, and used as material that will be mastered by students. In this study, the teaching materials developed were to make it easier for students to understand teaching materials during the lecture process [3].

Based on the description of the opinion above, it can be related in this study that teaching materials are a set of learning facilities and infrastructure and are closely related to everything that is used as a distributor of messages from the sender of the message to the recipient of the message, in this case the one who acts as the sender of the message is an educator (teacher). lecturers, and other types of educators) to students (students, students, and other students) as recipients of the message, so that the recipients of this message become interested in the development, their learning interest becomes high, so that it affects their high learning outcomes as well. This will be applied in the Research Methodology Course later.

Learning Research Methodology is a compulsory subject, which all students of the Department of Fine Arts Unimed must study, as a provision to conduct research later, [4] as stated by Sugiyono that research methodology is a scientific process or method to obtain data that will be used for research purposes. In research, here how a student can understand how to get data, based on facts and reality in the field, not fabricate according to his imagination, meaning that the data obtained is indeed true. When viewed from the word research, it is an investigative activity that is directed at obtaining increased knowledge, and is also a wellorganized and directed struggle to investigate certain problems to get an answer [5]. Methodology This research is included in educational research, where educational research is quite complicated and not easy to learn, this is due to the many theories of education itself which sometimes contradict each other [6].

This condition is proven by several events that the authors observed while students were conducting research, only a small number of students conducted field observations to collect data and facts about field problems before conducting research, most of them made research problems according to the wishes of the students themselves, without any facts and reality. The real problem, in fact, the problem appears suddenly and is just made up by the student concerned. This existing condition will be minimized later, with the development of teaching materials in the Research Methodology Course which is innovated in the form of comics, which will explain how to collect data and facts in the field when observing research problems that will be carried out later. A person's desire for something can be called an interest, where interest is closely related to the liking or pleasure of someone towards an object or an activity. This is like what was stated by Slameto [7] which states that interest is a sense of preference and a sense of interest in a thing or activity, without anyone telling. Interest is basically the acceptance of a relationship between oneself and something outside oneself. The stronger or closer the relationship, the greater the interest. If it is brought in learning, interest in learning has a huge influence on a learning outcome itself because, someone (student) will work seriously, well, and correctly with something that he is interested in [8].

[9] Furthermore Azis reveals that interest is a preference for something that arises from within (internal) and influences from outside (external). This interest arises without any coercion from anyone, is a will of oneself, the thing that is of interest is something that is interesting to have or do for a future career. According to Fimansyah [10] revealed that a student's interest will also affect his learning outcomes. Interest can be interpreted as a great desire for something that is owned by someone. Based on the description of the interests above, it is hoped that the development of teaching materials in the form of comics in this 
Research Methodology Course can increase the interest of students of the Department of Fine Arts arising from within (internal) interest in something that interest comes from outside (external), generates the desire to approach, study, touch, and so on more closely, so that it gains the desire to study higher and of course obtain high learning outcomes as well.

A result is carried out after carrying out learning activities then conducting an assessment and obtaining results, the results are high and some are low, early it can be seen that learning outcomes will be determined from the interest in learning itself, which will be directly proportional if interest in learning is high then learning outcomes of course high, and vice versa. Learning achievement is the mastery of knowledge or skills developed through subjects (MP), usually indicated by test scores or scores given by a lecturer [11]. Furthermore, [12] Hamalik reveals about learning outcomes, that a learning outcome is a change in behavior in a person that can be observed and measured in terms of knowledge, attitudes, and skills. These changes can be interpreted as an increase and development that is better than before where those who do not know become aware. Learning outcomes have many factors that affect it, including health, psychological, and it can also be due to fatigue, but there are other important factors, namely from family, school or campus (media or teaching materials), and also from the community [13]. Based on the description above, it can be concluded that learning outcomes are the values obtained by a student (in this case a student) after participating in learning, carrying out tests, in the form of numbers or letters. So the learning outcomes here are all outputs in the form of numbers or statements of high interest in learning because of the innovation of interesting teaching materials so as to obtain high learning outcomes as well. A learning process, of course, in the future, obtains the good or bad of the ability of students' learning outcomes. After being given a test, learning outcomes will be obtained, learning outcomes can be in the form of cognitive, practice, and other test results [14].

Comic Book is a term from English if in Indonesian it can be called "Komik Book" where comics are a medium used to express ideas with images, which are often combined with text or other visual information. Comics often take the form of juxtaposed panel sequences. Often textual tools such as balloons, captions, and onomatopoeias indicate the presence of dialogue, narration, sound effects, or other information. The size and arrangement of the panels contribute to the speed of the narration. Cartoons and similar forms of illustration are the most common way of creating images in comics [15]. Furthermore, comics are pictures and other symbols juxtaposed (nearby, next to each other) in a certain order that aims to provide information or to achieve an aesthetic response from readers [16]. Comics are one of the means of communication media in the form of literary works of images. Comics have been a part of Indonesian people's lives for a long time [17].

\section{Method}

Based on the purpose of this research, which is to produce teaching materials or onlinebased learning modules (e-books) and prints with ISBN that are valid, practical, and effective, therefore, this research is included in the type of development research. The following is a flow chart of the research and development that will be carried out: 


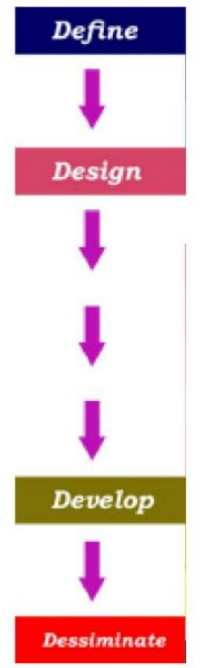

Fig. 1. Research Development Flowchart.

This research will be conducted using 4D models (four-D models). [18] According to Thiangarajan the development of the four-D model consists of 4 (four) stages: 1). Definition (define), 2). Design (design), 3). Development (develop), and 4). Spread (dessiminate). This research only reached the development stage, namely stage 3 (three), while the disseminate was not carried out, citing time and cost constraints of course. The research location is focused on the Department of Fine Arts, Faculty of Language and Arts Unimed, which is the object of this research are Fine Arts students who are taking Research Methodology Courses, there are classes A, B, C, and D, each class can be averaged 26 students. The research was conducted in the Even Semester of the Academic Year 2020/2021 on the class schedule of the Students of the Department of Fine Arts in the Research Methodology Course.

\section{Results and Discussion}

\subsection{Validation}

The results of the validation of each validator obtained a score as follows:

Table 1. Validator Assessment Results.

\begin{tabular}{ccc}
\hline Variable & Achievement (\%) & Category \\
\hline Module Contents & $91 \%$ & Very Valid \\
\hline Construction & $90 \%$ & Very Valid \\
\hline Language & $91 \%$ & Very Valid \\
\hline Module Display & $94.5 \%$ & Very Valid \\
\hline Average & $\mathbf{9 1 . 6 2 \%}$ & Very Valid \\
\hline
\end{tabular}


Analysis of the validator's assessment score of 4 (four) variables describes that, 1). The content of the module is at the achievement of a score of $91 \%$ in the very valid category, 2 ). Construction is at $90 \%$ into the very valid category, 3). Language variable is at $91 \%$ into the very valid category, and 4). Display Modules are at $94.5 \%$ fall into the very valid category as well. Based on the achievement of the score above, it can be taken the average of the four variables $91.62 \%$ of the average results are included in the very valid category. Comparison of the degree of achievement of module validation results on each variable that has been assessed by the validator can be seen in figure 2 below:

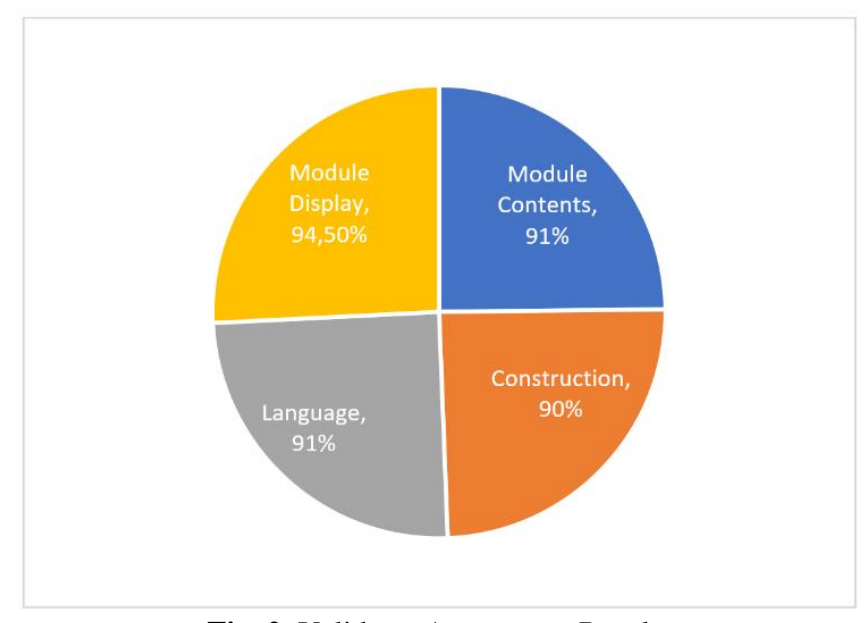

Fig. 2. Validator Assessment Results.

\subsection{Module Practicality}

The results of the practicality of the module from this study obtained the following data:

Table 2. Student Practical Results.

\begin{tabular}{ccc}
\hline Variable & Achievement $\mathbf{( \% )}$ & Category \\
\hline Convenience for users & $88.5 \%$ & Practical \\
\hline Usability & $94 \%$ & Very Practical \\
\hline Time effectiveness & $91 \%$ & Very Practical \\
\hline Average & $\mathbf{9 1 . 2 \%}$ & Very practical \\
\hline
\end{tabular}

The results obtained from the analysis of assessment data from students of the Fine Arts Education Study Program, Department of Fine Arts, Faculty of Language and Arts, Universitas Negeri Medan which is also the object of testing this module, there are 3 (three) variables, namely 1). Ease for Users (Learnability) with an achievement of $88.5 \%$ feels in the practical category, 2). Efficiency is at the achievement of $94 \%$ in the very practical category, and 3). The Effectiveness of Time is at $91 \%$, this shows that it is in the very practical category. Effectiveness in the teaching and learning process is a quality standard that has a measure of achieving goals, it can also be said to be precise in managing a situation or also called "doing the right things" (Miarso in Rohmawati, 2015: 16). The average value of practicality by students with an achievement level of $91.2 \%$ then from these results it can be said that the 
module is in the very practical category. More clearly the achievement of module practicality by students can be seen in figure 3 below:

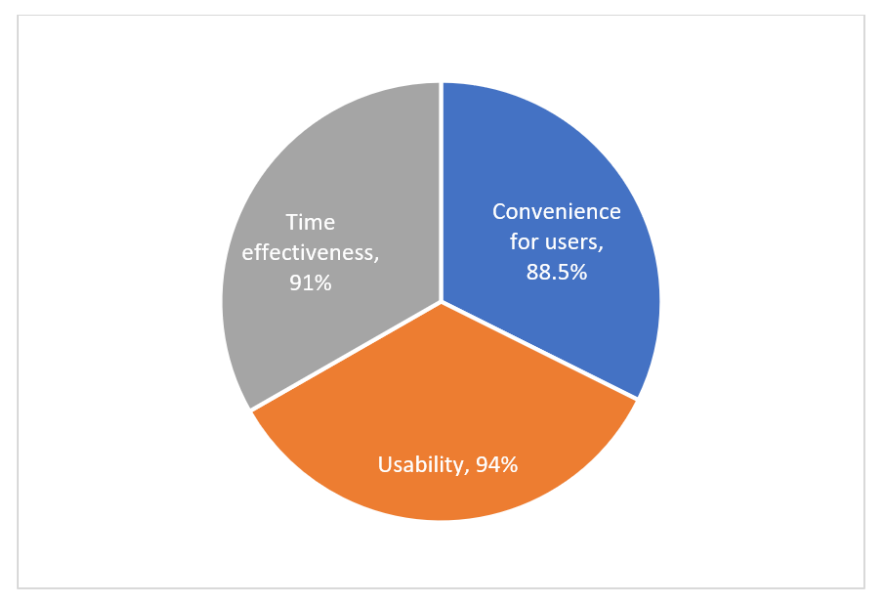

Fig. 3. Student Practical Results.

\subsection{Module Effectiveness}

Some of the activities seen by observers are as follows: a). Reading modules and doing exercises; b). Giving questions to the lecturer concerned while participating in the teaching and learning process; c). Provide answers to all the questions given by the lecturer concerned; and D). Collect assignments given by the lecturer. The first activity was reading the module and doing the exercises, the presentation of student activities reading the module and doing the exercises from the first meeting to the second meeting was at $100 \%, 100 \%, 100 \%$, and $100 \%$. On average $100 \%$ entered into the active category once. In the second activity, students asked questions to the lecturer while participating in the teaching and learning process. The percentages of activity from the first meeting to the fourth meeting are as follows: $66 \%$, $58.62 \%, 50 \%$, and $56 \%$, with an average of $58.2 \%$, so they fall into the fairly active category. Based on the data above, students who asked questions to the lecturers at these four meetings experienced a decrease in the second and third meetings, but increased in the fourth meeting. It can be said that learning using modules can improve student learning outcomes.

In the third activity, students answered questions from lecturers and questions from colleagues. The percentages of these four meetings are as follows: $60 \%, 58.5 \%, 61 \%$, and $62 \%$, so it can be averaged $60.37 \%$. This can be categorized as active students. Based on the percentage data above, it can be said that students experienced an increase from the first meeting to the fourth meeting in answering questions from lecturers and colleagues. The fourth activity completes the tasks given by the lecturer. All students collect their assignments from the first meeting to the second meeting where the percentage for each meeting is as follows: $100 \%, 100 \%, 100 \%$, and $100 \%$, with an average student activity of $100 \%$, it can be categorized as a student very active. The tasks given must be completed by each individual, so each student has responsibility for the tasks given by the lecturer. The average student activity above from each category can be seen in general in table 3 below: 
Table 3. Module Effectiveness Results.

\begin{tabular}{ccc}
\hline Student Activity Category & Achievement (\%) & Category \\
\hline $\begin{array}{c}\text { Reading modules and doing } \\
\text { exercises }\end{array}$ & $100 \%$ & Very Active \\
\hline $\begin{array}{c}\text { Questions to the lecturer } \\
\begin{array}{c}\text { Provide answers to all questions } \\
\text { posed by lecturers and colleagues }\end{array}\end{array}$ & $58.2 \%$ & Active Enough \\
\hline $\begin{array}{c}\text { Collect assignments given by the } \\
\text { lecturer }\end{array}$ & $60.37 \%$ & Active \\
\hline Overall Average & $100 \%$ & Very Active \\
\hline
\end{tabular}

The results of the analysis of student activities during the learning process with an average achievement level of $79.64 \%$ this number indicates that they are in the category of active students. To see a comparison of the things above can be seen in figure 4 below:

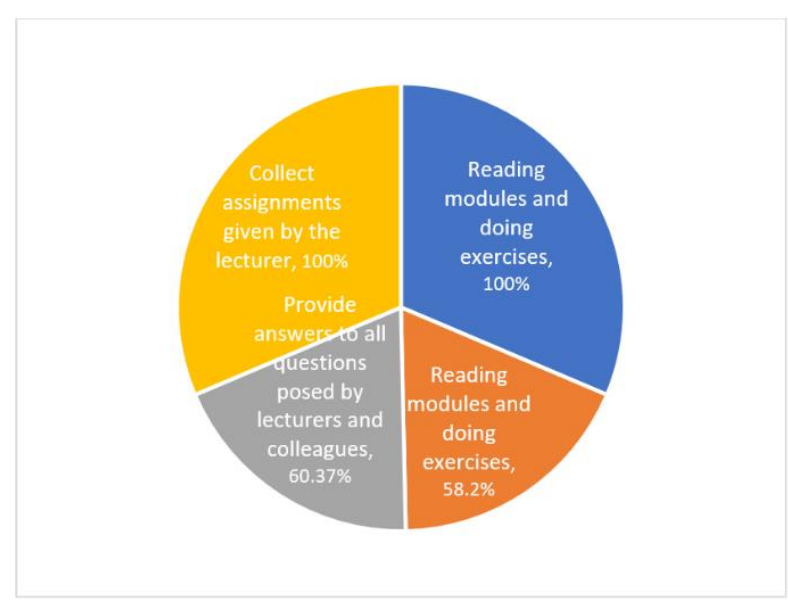

Fig. 4. Module Effectiveness Results.

\section{Conclusion}

Based on the explanation of the results of the validator's assessment, student practicality, and student activity achievements, it can be described as follows: 1). Module Content, Construction, Language, and Display of the Module are at $91.62 \%$, this indicates that the module is in the very valid category. The description of the contents of the module is arranged systematically, this makes it easier for users to understand the module. The module is formulated in a learning unit that begins with the presentation of the material and evaluation. The presentation of the module is in accordance with the student's ability level. Ease for users (Learnability) of the module, namely the lecturer as a guide in the learning process with a value of $88.5 \%$ is in the practical category for users. Where the module has instructions, language according to student characteristics, can be used individually, and the exercises contained in the module can assist lecturers in providing direction to students to understand concepts. The purpose of designing the module is to make it easier for lecturers to guide and 
direct students in the learning process. The usability of the module for students (Efficiency) with a score of $94 \%$ is in the very practical category. Modules can help students in explaining concepts. It is also expected to be able to help lecturers direct students in the learning process.

Effectiveness of Time is in the very practical category with an achievement value of $91 \%$. The modules developed are practically used by lecturers to guide students in the learning process. The results of the student learning evaluation can be declared as passing as many as 20. The percentage of students who pass is $100 \%$. The purpose of the evaluation is to determine whether the students being taught already have the competencies that have been determined so that they are worthy of being given the next learning material. The practicality of the module proves that, 20 students who use the module in the learning process, $100 \%$ of students are declared complete. Furthermore, based on observations observed by one observer, generally students are active in the learning process. This shows that the module is very practical and effectively used in the learning process and can increase student interest in the teaching and learning process.

Modules have been produced in the form of online and print-based comics in the Research Methodology Course, which aims to increase students' knowledge, skills, interests, and learning outcomes during the teaching and learning process. The value of the validity of the module is at $91.62 \%$ in the very valid category. The practicality value of the module by students is at an achievement level of $91.2 \%$, it can be categorized as very practical and able to increase user interest in the learning process, and for student activities it is in the active category because it is in the percentage of $79.64 \%$. This shows that the module has had a positive influence on students' knowledge in studying and understanding comic books in the Research Methodology Course.

The suggestions in this study are to attract the interest and desire to learn a student not only pay attention to the aspect of teaching. But there are other aspects, namely related to interesting media or teaching materials, so that if two things between good teaching methods and interesting teaching media are combined into a unified whole, it will certainly produce better learning outcomes as well. Towards a generation that excels among students, especially students of Fine Arts, it is necessary for the readiness of lecturers to innovate to find interesting new things to increase the attention and desire of students to study harder, whose main goal is to obtain good learning outcomes as well. It is also necessary to collaborate between fellow lecturers in producing further innovative studies, which seek other sides that have not been reached by previous researchers, to be investigated in a more interesting and useful finding.

Acknowledgments. The author would like to thank the Dean of the Faculty of Language and Arts and the Head of the Department of Fine Arts who have given permission to the author to carry out this Faculty research, then to all students of the Department of Fine Arts, Faculty of Language and Arts, Unimed who have been involved in the implementation of this research, and in particular to the Institute for Research and Community Service, State University of Medan regarding the BOPTN-2021 funding for the implementation of this research, so that this research goes well.

\section{References}

[1] Rusdi, Susilana, Riyana C. Media Pembelajaran Hakikat Pengembangan, Pemanfaatan, dan Penilaian. Bandung: Wacana Prima; 2007. 
[2] Hernawan AH, Permasih H, Dewi L. Pengembangan Bahan Ajar. Direktorat UPI Bandung. 2012; 4(11):01-013.

[3] Ramziah S. Peningkatan Kemampuan Representasi Matematis Siswa Kelas X2 SMAN 1 Gedung Meneng Menggunakan Bahan Ajar Matriks Berbasis Pendekatan Saintifik. Mosharafa: J Pend Matematika. 2016; 5(2):138-147.

[4] Sugiyono S. Memahami Penelitian Kualitatif. Bandung: ALFABETA; 2012.

[5] Wikipedia. Metodologi Penelitian. Available from: https://id.wikipedia.org/wiki/Metodologi_penelitian\#cite_note-google.co.id-2. [Accessed $12^{\text {th }}$ March 2021].

[6] Arifin Z. Bumi SA, Way A. Metodologi Penelitian Pendidikan Educational Research Methodology. J Penelit Pendidik. 2018; 1(2):01-05.

[7] Slameto S. Belajar dan Faktor-Faktor yang Mempengaruhinya. Jakarta: Rineka Cipta; 2003.

[8] Aritonang KT. Minat dan Motivasi dalam Meningkatkan Hasil Belajar Siswa. J Pend Penabur. 2008; 7(10):11-12.

[9] Azis ACK. Pengembangan Materi Ajar Komik pada Mata Kuliah Menggambar Ilustrasi untuk Meningkatkan Motivasi dan Hasil Belajar Mahasiswa Seni Rupa dalam Membuat Penugasan KKNI Revitalisasi 2018. Medan: Research Results Report is not Published; 2018.

[10] Fimansyah D. Pengaruh Strategi Pembelajaran dan Minat Belajar Terhadap Hasil Belajar Matematika. Judika (J Pend UNSIKA). 2015; 3(1):34-44.

[11] Alwi H, et al. Kamus Besar Bahasa Indonesia. Jakarta: Balai Pustaka; 2002.

[12] Hamalik O. Manajemen Pelatihan Ketenagakerjaan Pendekatan Terpadu Pengembangan Sumber Daya Manusia. Jakarta: Bumi Aksara; 2007.

[13] Nurhasanah S, Sobandi A. Minat Belajar sebagai Determinan Hasil Belajar Siswa. J Pend Manaj. Perkantoran (JPManper). 2016; 1(1):128-135.

[14] Rijak S, Bachtir S. Hubungan Antara Sikap, Kemandirian Belajar, dan Gaya Belajar dengan Hasil Belajar Kognitif Siswa. J Bioedukatikal. 2015; 3(2):15-20.

[15] Wikipedia. Komik. Available from: https://id.wikipedia.org/wiki/Komik [Accessed $12^{\text {th }}$ March 2021].

[16] McCloud S. Understanding Comics. Jakarta: Gramedia; 2001.

[17] Soedarso. Komik: Karya Sastra Bergambar. Humaniora. 2015; 6(4):496-506.

[18] Thiangarajan S, et al. Instructional Development for Training Teachers of Exceptional Children. Washington DC: National Center for Improvement Education System; 1974. 